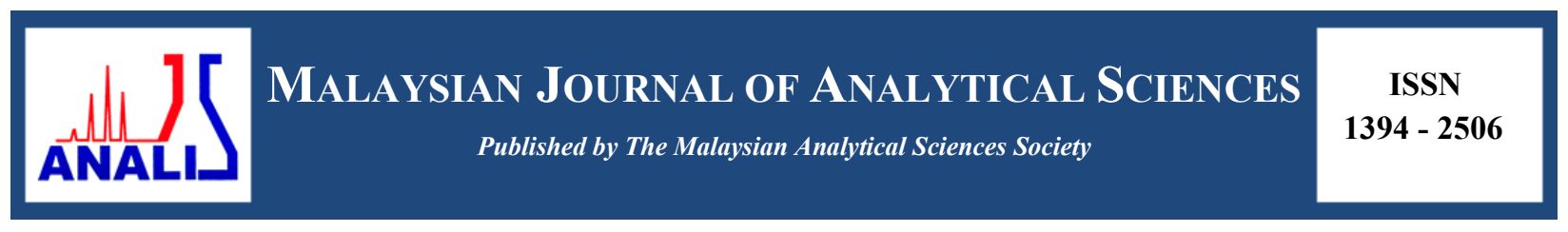

\title{
SYNTHESIS OF ZnO/rGO NANOHYBRID FOR IMPROVED PHOTOCATALYTIC ACTIVITY
}

\author{
(Sintesis Nanohibrid ZnO/rGO Untuk Mempertingkatkan Aktiviti Fotopemangkinan) \\ Marilyn Yuen Sok Wen ${ }^{1}$, Abdul Halim Abdullah ${ }^{1,2 *}$, Lim Hong Ngee ${ }^{1}$ \\ ${ }^{I}$ Department of Chemistry, Faculty of Science \\ ${ }^{2}$ Materials Science and Characterization Lab., Institute of Advanced Technology \\ Universiti Putra Malaysia, 43400 UPM Serdang, Selangor, Malaysia \\ *Corresponding author: halim@upm.edu.my
}

Received: 20 September 2016; Accepted: 16 May 2017

\begin{abstract}
Nanohybrids of zinc oxide/reduced graphene oxide $(\mathrm{ZnO} / \mathrm{rGO})$ with varying graphene oxide content were prepared via precipitation and were subsequently utilised in the photodegradation of methyl orange (MO) under UV light irradiation. The prepared photocatalysts were characterized by X-ray Diffraction (XRD), Field Emission Scanning Electron Microscopy (FESEM), Transmission Electron Microscopy (TEM) and Raman spectroscopy. The surface area and the band gap energy of the photocatalysts were determined by the Brunauer-Emmett-Teller method and UV-visible spectroscopic analysis. The ZnO/rGO nanohybrids produced had smaller particle sizes and lower band gap energy than that of $\mathrm{ZnO}$. All the $\mathrm{ZnO} / \mathrm{rGO}$ nanohybrids demonstrated better photocatalytic efficiency in the photodegradation of $\mathrm{MO}$ compared to $\mathrm{ZnO}$. $\mathrm{ZnO} / \mathrm{rGO} 10$ exhibited the highest photocatalytic activity with a rate constant that was four times higher than pure $\mathrm{ZnO}$ and about $40 \%$ enhancement in the photocatalytic activity for the removal of methyl orange within 3 hours. The enhanced photocatalytic performance of the $\mathrm{ZnO} / \mathrm{rGO}$ photocatalysts was due to the efficient transfer of photogenerated electrons to the graphene sheet that inhibited the recombination of electron-hole pairs.
\end{abstract}

Keywords: zinc oxide, reduced graphene oxide, nanohybrid, precipitation method, photocatalysis

\begin{abstract}
Abstrak
Nanohibrid zink oksida/grafin oksida terturun $(\mathrm{ZnO} / \mathrm{rGO})$ dengan kandungan grafin oksida yang berbeza telah disediakan melalui kaedah pemendakan dan seterusnya digunakan dalam fotodegradasi metil jingga (MO) di bawah sinaran cahaya UV. Fotopemangkin yang disediakan telah dicirikan dengan menggunakan pembelauan sinar-X (XRD), mikroskopi pengimbasan elektron (FESEM), mikroskopi transmisi elekron (TEM) dan spektroskopi Raman. Luas permukaan dan tenaga jurang jalur fotomangkin telah ditentukan menggunakan kaedah Brunauer-Emmett-Teller dan analisis spektroskopi UV-sinar nampak. Nanohibrid $\mathrm{ZnO} / \mathrm{rGO}$ yang terhasil mempunyai saiz zarah yang lebih kecil dan tenaga jurang jalur yang lebih rendah berbanding dengan $\mathrm{ZnO}$. Nanohibrid $\mathrm{ZnO} / \mathrm{rGO}$ mempamerkan kecekapan fotopemangkinan yang lebih tinggi dalam fotodegradasi $\mathrm{MO}$ berbanding dengan $\mathrm{ZnO}$. $\mathrm{ZnO} / \mathrm{rGO} 10$ mencatatkan aktiviti fotopemangkinan yang tertinggi dengan pemalar kadar empat kali ganda lebih tinggi daripada $\mathrm{ZnO}$ dan peningkatan $40 \%$ dalam aktiviti fotopemangkinan degradasi metil jingga dalam masa 3 jam. Peningkatan prestasi fotopemangkinan pemangkin $\mathrm{ZnO} / \mathrm{rGO}$ adalah disebabkan oleh kecekapan pemindahan fotojanaan elektron ke lembaran grafin yang seterusnya menghalang penggabungan semula pasangan elektron-lubang.
\end{abstract}

Kata kunci: zink oksida, grafin oksida terturun, nanohibrid, kaedah pemendakan, fotopemangkinan 


\section{Introduction}

Water pollution due to effluents from textile industries, especially dyes is a cause of serious concern. It is estimated that $1 \%$ to $15 \%$ of the dye is lost during the dyeing processes which is subsequently released into natural water resources and the wastewater system [1]. When released into the water, dyes may change the colour of the water, impact light penetration and reduce the solubility of gases [2].This in turn, has a serious impact on the aquatic ecosystem. Dyes are also stable and difficult to be biodegraded due to their synthetic origins and complex aromatic structures [3]. Hence, it is important to treat water resources and wastewaters containing such organic pollutants. Photocatalysis has long been introduced as a means of water decontamination [4]. Photocatalysis involves utilizing electron- hole pairs generated upon the irradiation of light to degrade organic molecules adsorbed on the surface of the photocatalyst [5]. This green technique can be performed in an ambient environment and may also oxidize organic carbon into carbon dioxide [6].

The use of zinc oxide $(\mathrm{ZnO})$ as a photocatalyst has several advantages including a low production cost, wide band gap $(\sim 3.37 \mathrm{eV})$, high stability and catalytic activity, better sensitivity in UV light and the presence of its many active sites with high surface reactivity [7-9]. However, the fast recombination of the electron-hole pairs of $\mathrm{ZnO}$ has limited its catalytic efficiency [10]. Recently, many attempts have been carried out to enhance the performance of $\mathrm{ZnO}$ photocatalysts by modifications with noble metal loading, ion doping or the incorporation of electronaccepting materials to extend the light absorption range to the visible light region or to suppress the electron-hole recombination process [11].

Graphene, a two-dimensional (2D) single-layered carbon sheet with an $\mathrm{sp}^{2}$ network of carbon atoms has excellent conductivity, good chemical stability, mechanical flexibility, a high mobility of charge carriers and a large specific surface area [12].These properties enable graphene to be an ideal support in combination with semiconductor photocatalysts. Graphene can be prepared by reducing graphene oxide (GO) [13]. The presence of oxygencontaining functional groups on the surface of the reduced graphene oxide (rGO) also makes graphene an excellent supporting material by anchoring strongly to the metal oxide nanostructure $[14,15]$.

Many methods have been used to fabricate $\mathrm{ZnO}$ photocatalysts hybridised with rGO, including solvothermal [16], chemical deposition [11], hydrothermal [15, 17, 18] and sol- gel [19] methods. Herein, we report a simple precipitation method to prepare $\mathrm{ZnO} / \mathrm{rGO}$ nanohybrids with zinc acetate dihydrate and graphene oxide (GO) as the starting materials, and ammonia as both the precipitator and reductant. This study is focused on determining the effect of rGO on the structure and photocatalytic activity of $\mathrm{ZnO}$.

\section{Materials}

\section{Materials and Methods}

Zinc acetate dihydrate $\left(\left(\mathrm{CH}_{3} \mathrm{COO}\right)_{2} \mathrm{Zn} \cdot 2 \mathrm{H}_{2} \mathrm{O}\right)$ and $25 \%$ ammonia solution $\left(\mathrm{NH}_{3}\right)$ were purchased from Merck. Methyl orange (MO) $\left(\mathrm{C}_{14} \mathrm{H}_{14} \mathrm{O}_{3} \mathrm{~N}_{3} \mathrm{SNa}\right)$, a model pollutant, was obtained from Bendosen. All chemicals were used without further purification.

\section{Synthesis of graphene oxide}

GO was synthesized using a modified Hummers method [20]. In a typical experiment, graphite flakes, $\mathrm{H}_{2}$ $\mathrm{SO}_{4}: \mathrm{H}_{3} \mathrm{PO}_{4}(320: 80 \mathrm{ml})$ and $\mathrm{KMnO}_{4}(18 \mathrm{~g})$ were mixed together under magnetic stirring. The mixture was stirred for 3 days to allow the oxidation of graphite, where the colour of the mixture changed from dark purplish green to dark brown. The colour of the mixture changed to bright yellow after the addition of $\mathrm{H}_{2} \mathrm{O}_{2}$ solution. The graphite oxide formed was washed three times with $1 \mathrm{M} \mathrm{HCl}$ aqueous solution and repeatedly with deionized water using a centrifugation force of $10,000 \mathrm{~g}$ until wash-water with a $\mathrm{pH}$ of $4-5$ was obtained.

\section{Preparation of $\mathrm{ZnO} / \mathrm{rGO}$ nanohybrid photocatalyst}

The $\mathrm{ZnO} / \mathrm{rGO}$ nanohybrid was synthesized by mixing $10 \mathrm{ml}$ of $1 \mathrm{mg} / \mathrm{ml} \mathrm{GO}$ with $100 \mathrm{ml} 0.3 \mathrm{M}$ zinc acetate dihydrate solution followed by the addition of ammonia solution until a pH 10 of was achieved. The precipitate was later filtered and washed several times with deionised water and dried overnight in an oven at $100{ }^{\circ} \mathrm{C}$. The dried powder was then calcined at $400{ }^{\circ} \mathrm{C}$ for 2 hours and labelled as $\mathrm{ZnO} / \mathrm{rGO} 10$. In order to study the effect of GO content on the physicochemical properties and photocatalytic activity, three different nanohybrids were prepared by 
changing the initial volume of the GO solution. ZnO/rGO nanohybrids with a volume ratio of 5:100, 10:100 and 20:100 of GO and Zinc acetate dihydrate solution were denominated as $\mathrm{ZnO} / \mathrm{rGO}$, $\mathrm{ZnO} / \mathrm{rGO} 10$ and $\mathrm{ZnO} / \mathrm{rGO} 20$. For comparison, pure zinc oxide ( $\mathrm{ZnO})$ was also obtained using the same method without adding any GO.

\section{Characterization}

The phase and crystallinity of the samples were analysed using Philips PW 3040/60 MPD X-ray diffractometer with $\mathrm{Ni}$-filtered $\mathrm{CuK}_{\alpha}$ radiation. The X-ray diffraction (XRD) pattern were recorded in the $2 \theta$ range of $20^{\circ}-80^{\circ}$ at a scanning rate of $2 \% \mathrm{~min}$. The surface morphology of the samples was studied using Field Emission Electron Microscopy (FESEM) (FEI Nova Nanosem 230 combined with EDX) and Transmission Electron Microscopy (TEM) (Hitachi H-7100). The surface area of the samples was determined using a BET surface area analyzer (BELSorp Mini II). Raman spectroscopy (WITec Alpha 300R) was used to study the disordered crystal structure of the carbon based material and to confirm the presence of rGO. Diffuse reflectance spectra were recorded using a Shimadzu UV-3600 spectrophotometer in order to determine the band gap energy of the prepared samples.

\section{Photocatalytic activity experiment}

The photocatalytic performance of the prepared photocatalysts was evaluated in the photodegradation of methyl orange (MO) under the illumination of a $6 \mathrm{~W}$ UVA lamp for 3 hours. In a typical experiment, $0.5 \mathrm{~g}$ of photocatalyst was suspended in a photoreactor containing $500 \mathrm{ml}$ of $\mathrm{MO}$ solution $(10 \mathrm{ppm})$. The resultant solution was magnetically stirred in the dark for 30 minutes to reach an adsorption-desorption equilibrium prior to UV irradiation. An amount $5 \mathrm{ml}$ of test samples were taken at predetermined time intervals and were immediately filtered with a $0.45 \mu \mathrm{m}$ cellulose nitrate filter. The concentration of MO in the test samples was determined (Perkin Elmer Lambda 35 UV-Vis Spectrometer) at a wavelength of $464.3 \mathrm{~nm}$.

\section{X-ray diffraction}

\section{Results and Discussion}

Figure 1 displays the XRD patterns of pure $\mathrm{ZnO}$ and $\mathrm{ZnO} / \mathrm{rGO}$ nanohybrid photocatalysts. The diffraction peaks observed in the XRD pattern of the prepared photocatalysts were consistent with the hexagonal wurtzite phase of $\mathrm{ZnO}$ (JCPDS No. 36-1451). The peaks at $2 \theta=31.8^{\circ}, 34.4^{\circ}, 36.2^{\circ}, 47.5^{\circ}, 56.6^{\circ}, 62.8^{\circ}, 66.4^{\circ}, 68.0^{\circ}, 69.1^{\circ}, 72.5^{\circ}$ and $77.0^{\circ}$ are associated with the $100,002,101,102,110,103,200,112$ and 203 crystalline planes of $\mathrm{ZnO}$, respectively. However, no characteristic peak for rGO was observed in the XRD patterns due to its low content and its relatively low diffraction intensity compared to $\mathrm{ZnO}$ [21-23]. The average crystallite size of $\mathrm{ZnO}$ and the $\mathrm{ZnO} / \mathrm{rGO}$ nanohybrid photocatalysts was calculated using Scherrer's equation and the data is shown in Table 1. It was also observed that the intensity of the diffraction peaks of the $\mathrm{ZnO} / \mathrm{rGO}$ nanohybrids decreased as the rGO content increased. This indicated that the crystallinity of $\mathrm{ZnO}$ deteriorated as the concentration of $\mathrm{ZnO}$ in the $\mathrm{ZnO} / \mathrm{rGO}$ nanohybrids decreased when compared to pure $\mathrm{ZnO}$ [24]. Kuo and co-workers [25] reported that an increase in the concentration of the dopant led to the formation of stresses because of the difference in ionic size of zinc and the dopant. $\mathrm{ZnO} / \mathrm{rGO}$ nanohybrids were observed to have smaller crystallite sizes when compared to pure $\mathrm{ZnO}$. This was due to the presence of the dopant, (rGO) which hindered the growth of crystal grains[26].

Table 1. Physical characteristics of $\mathrm{ZnO}$ and $\mathrm{ZnO} / \mathrm{rGO}$ nanohybrids.

\begin{tabular}{lccc}
\hline Photocatalyst & $\begin{array}{c}\text { Crystallite Size } \\
(\mathbf{n m})\end{array}$ & $\begin{array}{c}\text { Surface Area } \\
\left(\mathbf{m}^{\mathbf{2}} \mathbf{g}^{-\mathbf{1}}\right)\end{array}$ & $\begin{array}{c}\text { Band Gap Energy } \\
\mathbf{( e V )}\end{array}$ \\
\hline $\mathrm{ZnO}$ & 43 & 5.15 & 3.16 \\
$\mathrm{ZnO} / \mathrm{rGO5}$ & 32 & 7.78 & 3.05 \\
$\mathrm{ZnO} / \mathrm{rGO} 10$ & 36 & 9.70 & 3.08 \\
$\mathrm{ZnO} / \mathrm{rGO} 20$ & 32 & 7.48 & 3.05 \\
\hline
\end{tabular}




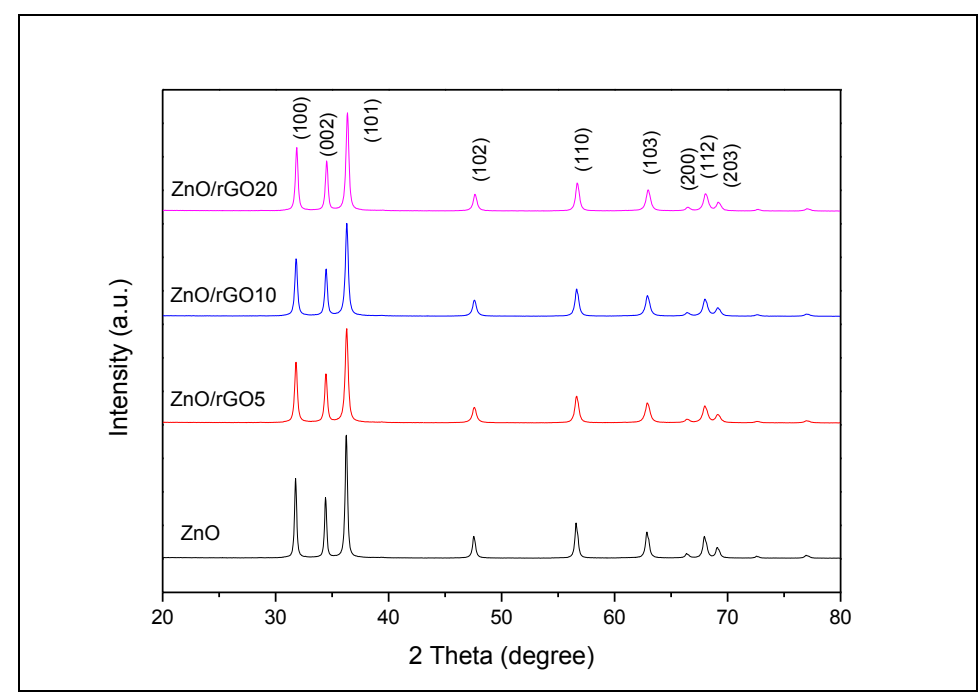

Figure 1. XRD patterns of $\mathrm{ZnO}$ and $\mathrm{ZnO} / \mathrm{rGO}$ nanohybrid photocatalysts

\section{Morphology}

The surface morphology of the $\mathrm{ZnO}$ and $\mathrm{ZnO} / \mathrm{rGO}$ nanohybrid photocatalysts, determined using TEM and FESEM, is shown in Figures 2 and 3, respectively. TEM images revealed the presence of $\mathrm{ZnO}$ on the surface of the graphene sheet. The $\mathrm{ZnO}$ nanoparticles were nearly spherical in shape, self-assembled and were randomly distributed on the graphene sheets. The formation of spherical $\mathrm{ZnO}$ nanoparticles could have been due to the addition of $\mathrm{OH}^{-}$ that increased the reaction rate, thus forming more nuclei in a short time [5]. The two- dimensional graphene sheets were not perfectly flat but rough with wrinkles. EDX were used to distinguish the components present in the samples. As shown in Figure 4, carbon $(\mathrm{C})$, zinc $(\mathrm{Zn})$ and oxygen $(\mathrm{O})$ were the main elements present in the $\mathrm{ZnO} / \mathrm{rGO}$ nanohybrid photocatalysts with no unexpected elements being detected. This confirmed the purity of the samples.
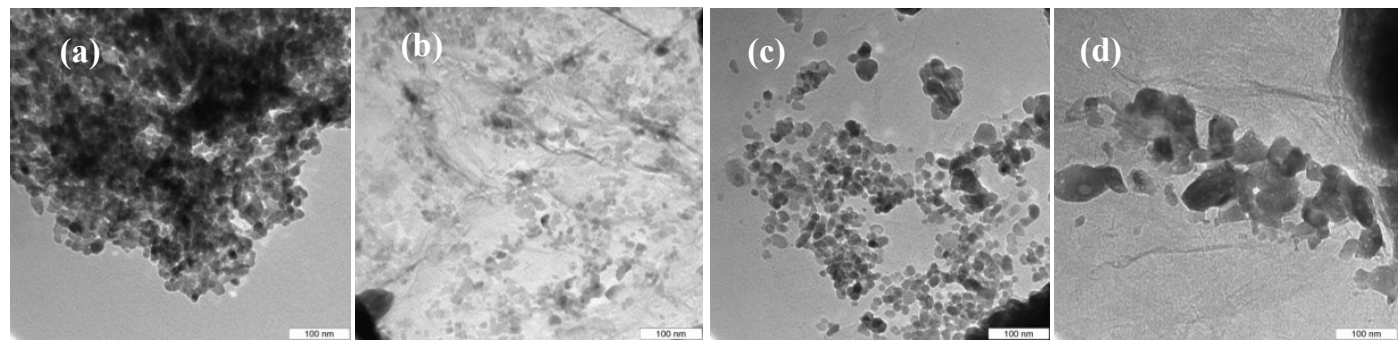

Figure 2. TEM images of (a) $\mathrm{ZnO}$, (b) $\mathrm{ZnO} / \mathrm{rGO}$, (c) $\mathrm{ZnO} / \mathrm{rGO} 10$ and (d) $\mathrm{ZnO} / \mathrm{rGO} 20$
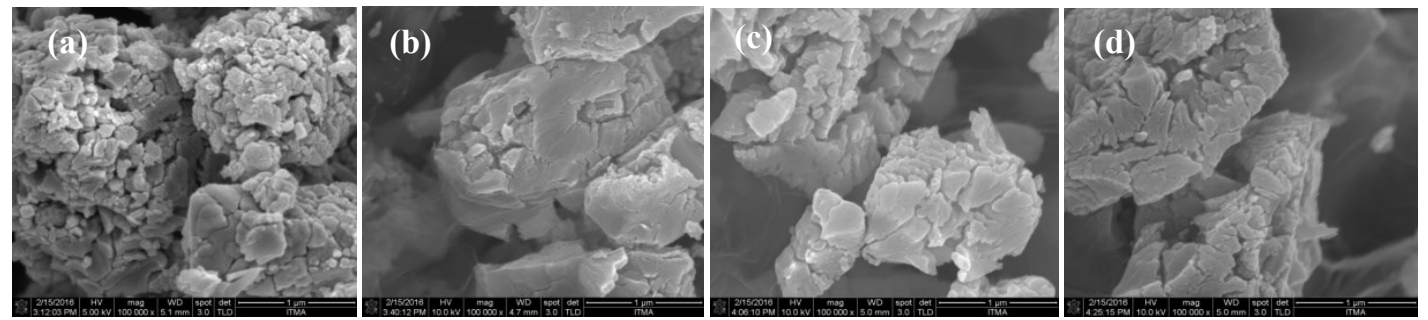

Figure 3. FESEM images of (a) $\mathrm{ZnO}$, (b) $\mathrm{ZnO} / \mathrm{rGO}$, (c) $\mathrm{ZnO} / \mathrm{rGO} 10$ and (d) $\mathrm{ZnO} / \mathrm{rGO} 20$ 

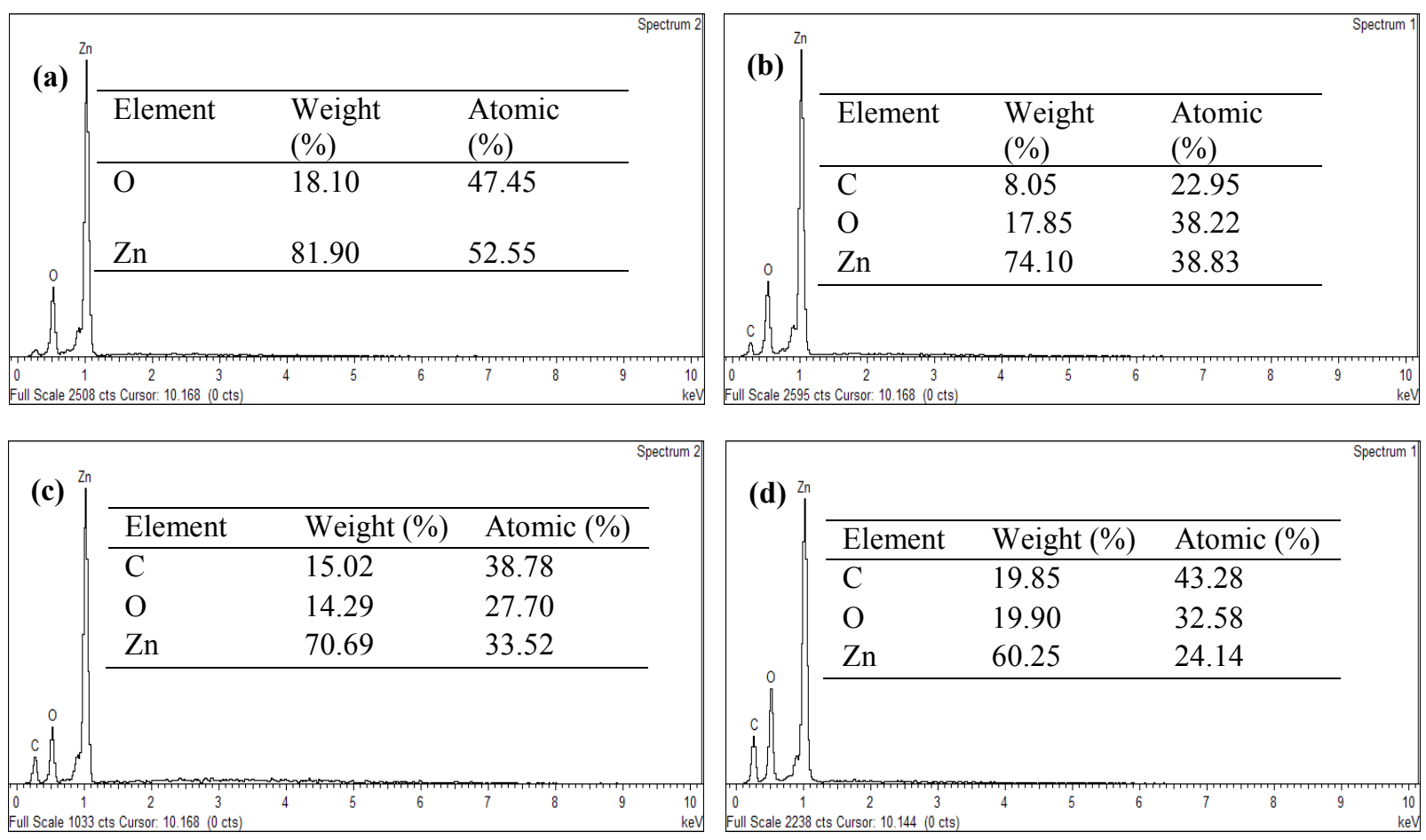

Figure 4. EDX spectra of (a) $\mathrm{ZnO}$, (b) $\mathrm{ZnO} / \mathrm{rGO}$, (c) $\mathrm{ZnO} / \mathrm{rGO} 10$ and (d) $\mathrm{ZnO} / \mathrm{rGO} 20$

\section{Surface area and porosity}

The BET surface areas of the $\mathrm{ZnO}$ and $\mathrm{ZnO} / \mathrm{rGO}$ nanohybrid photocatalysts were obtained from the nitrogen adsorption- desorption isotherm and the results are represented in Table 1. Both the $\mathrm{ZnO}$ and $\mathrm{ZnO} / \mathrm{rGO}$ nanohybrid photocatalysts met the type $\mathrm{V} \mathrm{N}_{2}$ adsorption- desorption isotherms with $\mathrm{H} 3$ hysteresis loop where there was a weak adsorbent- adsorbate interaction. The high adsorption at a relative pressure $\mathrm{P} / \mathrm{P}_{0}$ close to 1.0 also suggested the formation of large mesopores and macropores. Meanwhile, the presence of type H3 loop suggested the occurrence of macropores which are not completely filled with pore condensate [27]. It was observed that there was an improvement in the surface area of the $\mathrm{ZnO} / \mathrm{rGO}$ nanohybrids compared to $\mathrm{ZnO}$ where graphene was incorporated. The nanohybrids were expected to have better photocatalytic performance than $\mathrm{ZnO}$ as the high surface area enhanced the efficient adsorption and transfer of organic molecules in a photochemical reaction via $\pi-\pi$ conjugation between the organic molecules and graphene sheet [28].
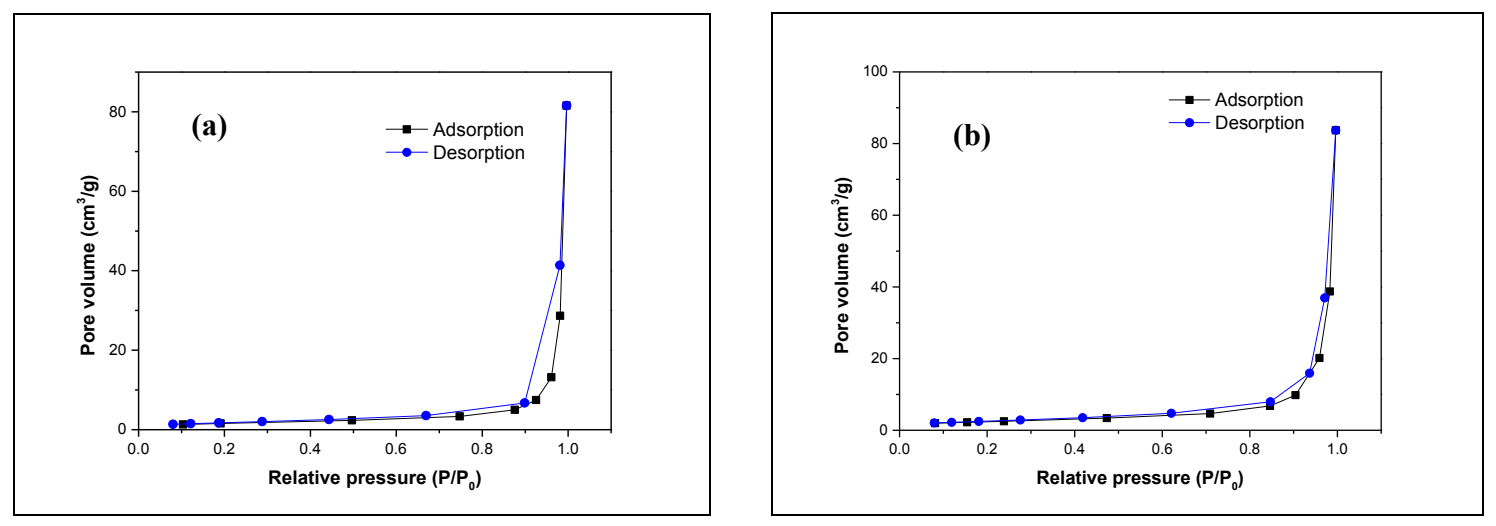

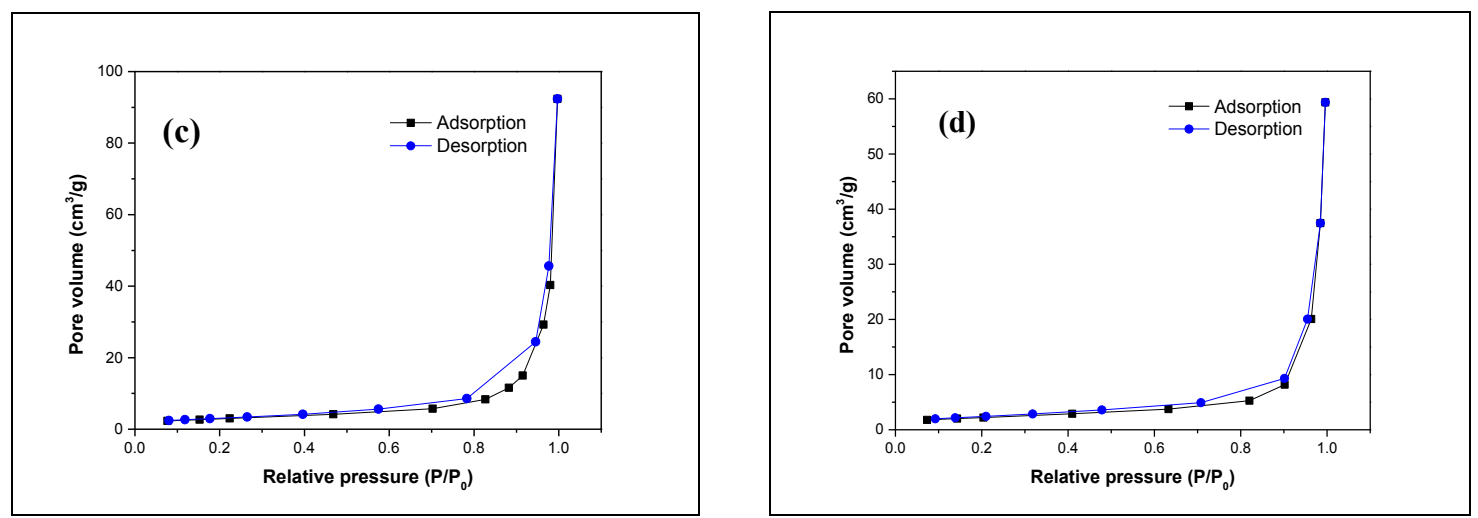

Figure 5. Nitrogen adsorption-desorption isotherm of (a) $\mathrm{ZnO}$ (b) $\mathrm{ZnO} / \mathrm{rGO} 5$ (c) $\mathrm{ZnO} / \mathrm{rGO} 10$ and (d) $\mathrm{ZnO} / \mathrm{rGO} 20$

\section{Raman spectroscopy}

Figure 6 shows the Raman spectra of GO, rGO and $\mathrm{ZnO} / \mathrm{rGO} 10$. The characteristic Raman peaks of all three samples showed similar D and G band structures of carbon, which was $1362 \mathrm{~cm}^{-1}$ and $1605 \mathrm{~cm}^{-1} ; 1352 \mathrm{~cm}^{-1}$ and $1605 \mathrm{~cm}^{-1} ; 1355 \mathrm{~cm}^{-1}$ and $1605 \mathrm{~cm}^{-1}$ for GO, $\mathrm{rGO}$ and $\mathrm{ZnO} / \mathrm{rGO} 10$, respectively. The $\mathrm{D}$ band refers to the presence of disorder in the graphene structure while the $\mathrm{G}$ band refers to the presence of an $\mathrm{sp}^{2}$ carbon type structure [29]. The $\mathrm{D}$ band in $\mathrm{ZnO} / \mathrm{rGO} 10$ was slightly blue shifted by $7 \mathrm{~cm}^{-1}$ compared to GO. This was due to the interaction between $\mathrm{ZnO}$ and $\mathrm{rGO}$ [28]. Similar D and $\mathrm{G}$ bands for $\mathrm{rGO}$ and $\mathrm{ZnO} / \mathrm{rGO} 10$ also suggested that the structure of rGO was maintained in the nanohybrid. However, there was a change in the electronic conjugation state of the GO as indicated by the change in the $\mathrm{G}$ and $\mathrm{D}$ band intensities after being incorporated into $\mathrm{ZnO}[12,30]$. The intensity ratios $\left(\mathrm{I}_{\mathrm{D}} / \mathrm{I}_{\mathrm{G}}\right)$ increased from 0.87 in $\mathrm{GO}$ to $0.98 \mathrm{in} \mathrm{ZnO} / \mathrm{rGO} 10$ implying that the $\mathrm{GO}$ was successfully reduced and more $\mathrm{sp}^{2}$ domains (graphene sheets) had formed [31]. This also indicated that the introduction of $\mathrm{ZnO}$ increased the defects or disorders in the GO sheet [32], hence confirming the formation of the $\mathrm{ZnO} / \mathrm{rGO}$ nanohybrid.

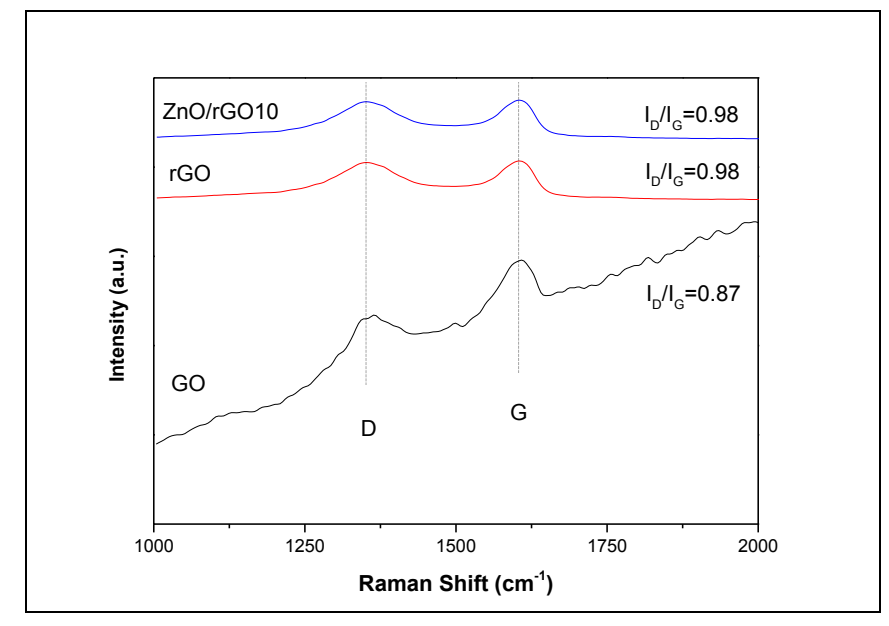

Figure 6. Raman spectra of GO, $\mathrm{rGO}$ and $\mathrm{ZnO} / \mathrm{rGO} 10$

\section{UV- visible diffuse reflectance spectroscopy}

Figure 7 shows that both $\mathrm{ZnO}$ and $\mathrm{ZnO} / \mathrm{rGO}$ nanohybrids had similar maximum absorptions at $360 \mathrm{~nm}$. There was an enhancement in the absorption intensity of the $\mathrm{ZnO} / \mathrm{rGO}$ nanohybrids corresponding to the increase in $\mathrm{GO}$ 
content in both the UV and visible regions as a result of the increase in the surface electric charge of the oxides and the modification of the fundamental process of electron- hole pair formation during irradiation [33, 34]. The band gap energy of both $\mathrm{ZnO}$ and $\mathrm{ZnO} / \mathrm{rGO}$ nanohybrids were determined by the extrapolation of the linear relationship between $(\alpha h v)^{2}$ and hv [35]:

$$
(\alpha h v)^{2}=K\left(h v-E_{g}\right)
$$

where $\alpha$ is the absorption coefficient, $K$ is the proportionality constant and $v$ is the frequency of photons.

A plot of $(\alpha h v)^{2}$ as a function of photon energy, $h v$ for all samples is illustrated in Figure 7 with the band gap values listed in Table 1 . The band gap energy of pure $\mathrm{ZnO}$ was slightly higher than that of the $\mathrm{ZnO} / \mathrm{rGO}$ nanohybrids. The reduction in band gap energy could be attributed to the formation of $\mathrm{Zn}-\mathrm{O}-\mathrm{C}$ chemical bonds in the nanohybrid $[17,36,37]$. This also indicated that the presence of graphene influenced the electronic energy level of the $\mathrm{ZnO}$ nano-particles. As the band gap energy reduced, more photons were prone to be absorbed by the nanohybrid which in turn would enhance the photocatalytic efficiency.

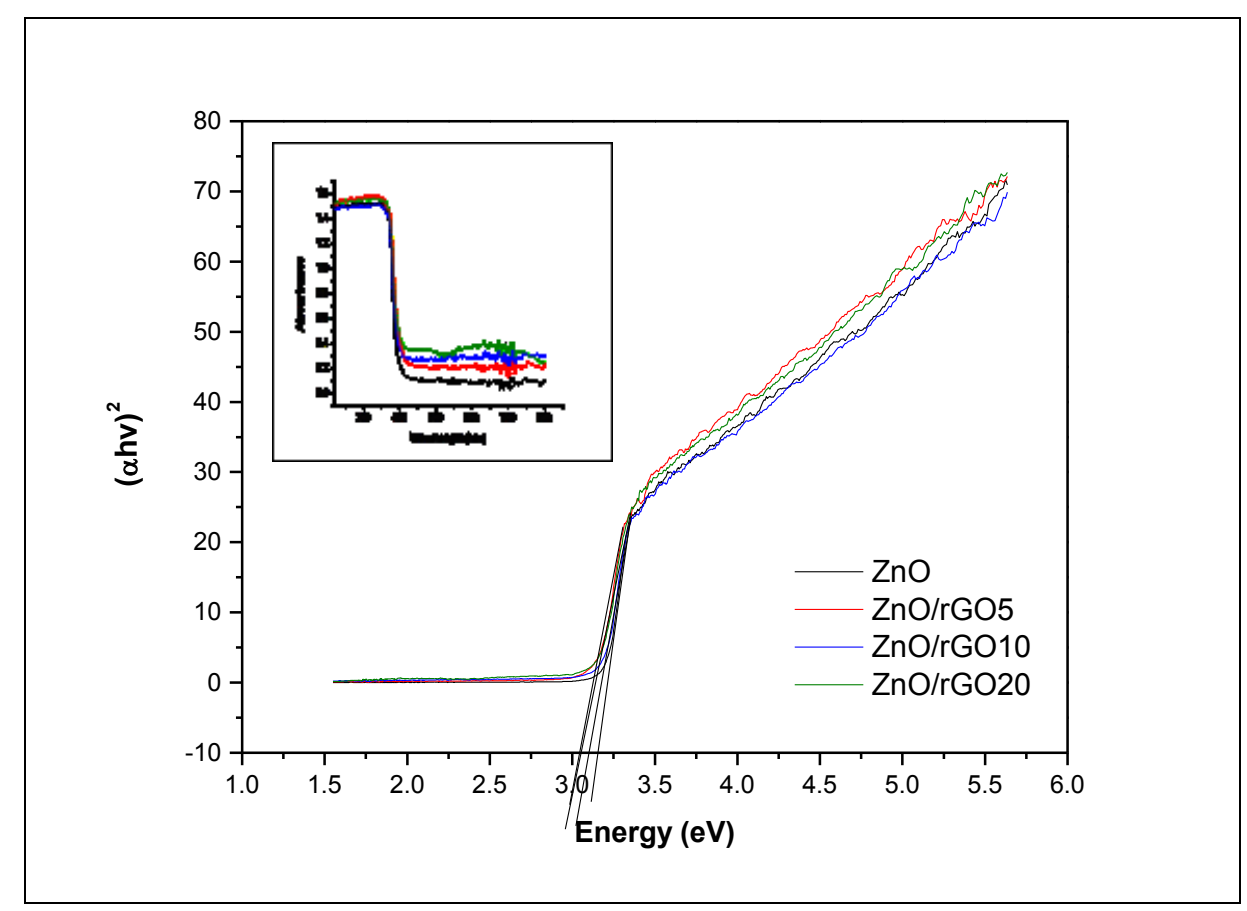

Figure 7. The plots of $(\alpha h v)^{2}$ versus $h v$ and UV spectrum (inset) for $\mathrm{ZnO}, \mathrm{ZnO} / \mathrm{rGO}$, $\mathrm{ZnO} / \mathrm{rGO} 10$ and $\mathrm{ZnO} / \mathrm{rGO} 20$

\section{Photocatalytic activities}

The photocatalytic performance of both the $\mathrm{ZnO}$ and $\mathrm{ZnO} / \mathrm{rGO}$ nanohybrid photocatalysts were evaluated by degrading methyl orange under the irradiation of UV light and the results are depicted in Figure 8. By comparison, only $53 \%$ of $\mathrm{MO}$ was degraded using pure $\mathrm{ZnO}$ after 180 minutes of irradiation. However, the $\mathrm{ZnO} / \mathrm{rGO}$ nanohybrids were found to show more prominent photocatalytic efficiency, with $80 \%, 97 \%$ and $77 \%$ of $\mathrm{MO}$ photodegraded for $\mathrm{ZnO} / \mathrm{rGO} 5, \mathrm{ZnO} / \mathrm{rGO} 10$, and $\mathrm{ZnO} / \mathrm{rGO} 20$, respectively.

In principle, the photocatalytic degradation of $\mathrm{MO}$ by $\mathrm{ZnO}$ and $\mathrm{ZnO} / \mathrm{rGO}$ nanohybrids is an interface process and follows the Langmuir-Hinshelwood model where it obeys the following assumptions: (i) limited adsorption sites on the catalyst's surface, (ii) monolayer coverage of the catalyst surface with single adsorptions on each site, (iii) reversible adsorption reactions, (iv) homogeneous catalyst surface and (v) zero interactions between the molecules 
adsorbed[38]. In this study, $\mathrm{H}_{2} \mathrm{O}, \mathrm{O}_{2}$ and dye (MO) were adsorbed on the surface of the catalyst in adjacent sites. The reaction then occurred between the adsorbed molecules and the radicals generated before the products $\left(\mathrm{CO}_{2}\right.$ and $\left.\mathrm{H}_{2} \mathrm{O}\right)$ were desorbed from the catalyst's surface.

$$
\begin{aligned}
& \mathrm{ZnO}+h v \rightarrow \mathrm{e}_{\mathrm{CB}^{-}}+h^{+}{ }_{\mathrm{VB}} \\
& \mathrm{H}_{2} \mathrm{O}+h^{+}{ }_{\mathrm{VB}} \rightarrow \mathrm{OH} \bullet+\mathrm{H}^{+} \\
& \mathrm{O}_{2 \text { (ads) }}+\mathrm{eCB}^{-} \rightarrow \mathrm{O}_{2}^{\cdot-} \\
& \mathrm{OH}^{-}{ }_{(\mathrm{ads})}+h^{+}{ }_{\mathrm{VB}} \rightarrow \mathrm{OH}_{(\mathrm{ads})} \text {. } \\
& \mathrm{OH}_{(\mathrm{ads})} \cdot+\mathrm{OH} \bullet \rightarrow \mathrm{H}_{2} \mathrm{O}_{2} \\
& \mathrm{H}_{2} \mathrm{O}_{2}+\mathrm{O}_{2}{ }^{--} \rightarrow \mathrm{OH} \bullet+\mathrm{OH}^{-}+\mathrm{O}_{2} \\
& \text { Dye }_{(\text {ads })}+\mathrm{OH} \bullet \rightarrow \mathrm{CO}_{2}+\mathrm{H}_{2} \mathrm{O}
\end{aligned}
$$
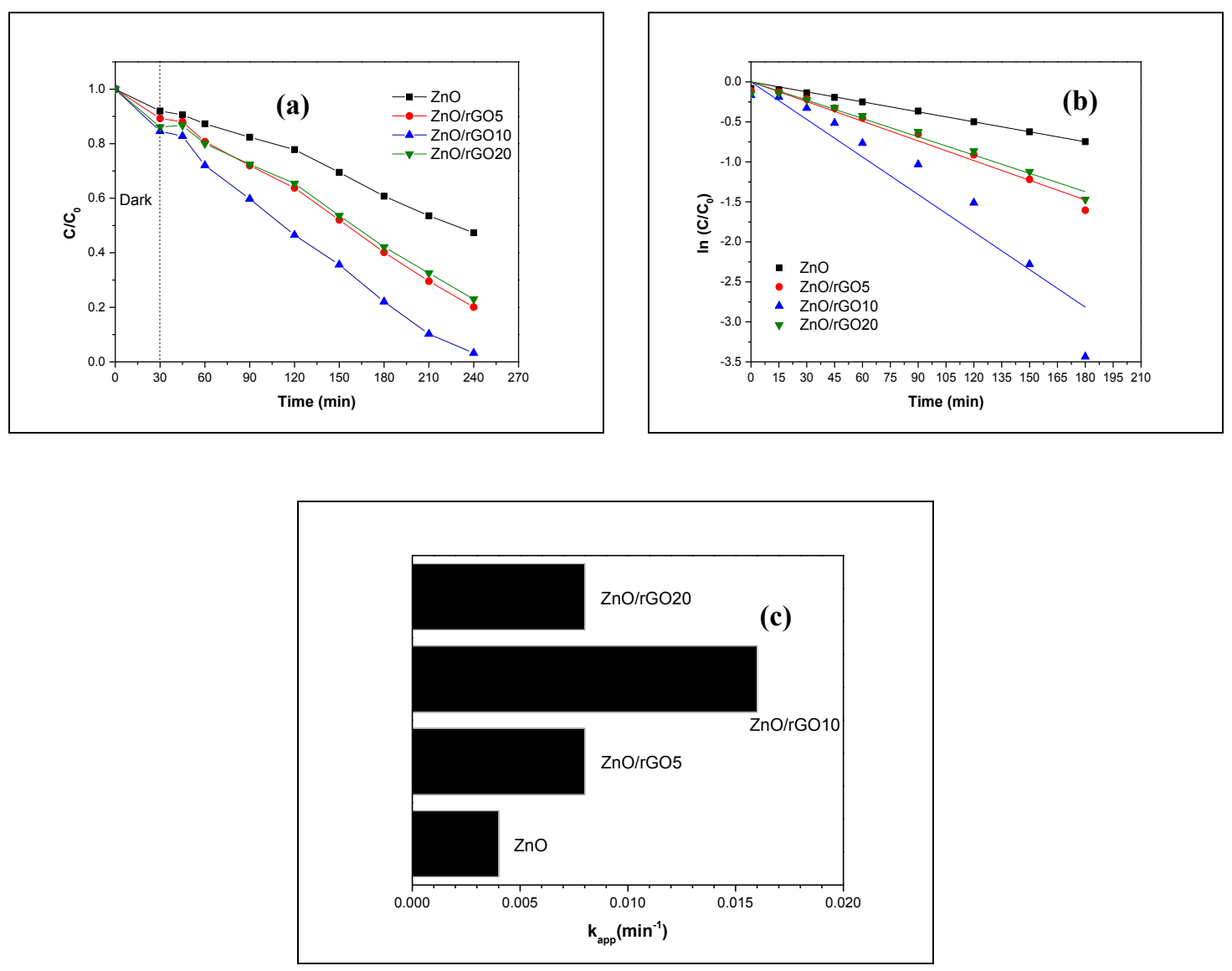

Figure 8. Photodegradation of $\mathrm{MO}$ by pure $\mathrm{ZnO}$ and $\mathrm{ZnO} / \mathrm{rGO}$ nanohybrid photocatalysts: (a) reaction profile (b) kinetics and (c) apparent rate constant [condition: $0.5 \mathrm{~g}$ of photocatalyst, $10 \mathrm{ppm} \mathrm{MO}, \mathrm{pH}=6.6$ ]

The data for the photocatalytic degradation of MO was fitted to the Langmuir-Hinshelwood kinetics model and the plot of $\ln \left(\mathrm{C} / \mathrm{C}_{0}\right)$ vs time (Figure $8 \mathrm{~b}$ ) showed that the photodegradation of $\mathrm{MO}$ followed a pseudo first order reaction. The pseudo first order kinetics for MO degradation was calculated as follows:

$$
\ln \left(\mathrm{C} / \mathrm{C}_{0}\right)={ }_{-} k t
$$


where $\mathrm{C}(\mathrm{mg} / \mathrm{L})$ is the initial concentration of $\mathrm{MO}, \mathrm{C}_{0}(\mathrm{mg} / \mathrm{L})$ is the concentration of $\mathrm{MO}$ at time $\mathrm{t}(\mathrm{min})$ and $k$ $\left(\mathrm{min}^{-1}\right)$ is the pseudo first order rate constant. The apparent rate constants, $\mathrm{k}_{\mathrm{app}}$, were determined from the slope of the plot and is illustrated in Figure 8c. It was clear that the $\mathrm{ZnO} / \mathrm{rGO}$ nanohybrid photocatalysts exhibited higher photocatalytic activities than pure $\mathrm{ZnO}$. The photocatalytic activity increased as the GO content increased until it reaches the optimum, in the order of $\mathrm{ZnO} / \mathrm{rGO} 10>\mathrm{ZnO} / \mathrm{rGO} 5>\mathrm{ZnO} / \mathrm{rGO} 20>\mathrm{ZnO}$. ZnO/rGO10 had the best photocatalytic activity with a kinetic rate constant $0.016 \mathrm{~min}^{-1}$, which was four times higher than pure $\mathrm{ZnO}$. The results were comparable with that reported in literature [21,28].

The enhancement in the photocatalytic performance of the $\mathrm{ZnO} / \mathrm{rGO}$ nanohybrids could be attributed to the strong interactions between $\mathrm{ZnO}$ and $\mathrm{rGO}$ and the defect sites of graphene. Graphene, with a two- dimensional conjugation structure [39], acted as an excellent electron acceptor. When $\mathrm{ZnO}$ was irradiated with UV light, the electrons were excited from the valence band to the conduction band, leaving behind holes in the valence band. These excited electrons could also be transferred from the conduction band of $\mathrm{ZnO}$ to the graphene sheet. The effective transfer of photoelectrons from the conduction band of $\mathrm{ZnO}$ to graphene prolonged the electron-hole pairs recombination hence promoting the separation of electron- hole pairs of $\mathrm{ZnO}[40,41]$. More charge carriers were produced from the reactive species which eventually helped in the degradation of MO [42]. The schemetic mechanism of the photocatalysis is shown in Figure 9. Moreover, the $\mathrm{ZnO} / \mathrm{rGO}$ nanohybrid had a smaller particle size, larger surface area and lower band gap energy compared to $\mathrm{ZnO}$. Such structural changes in $\mathrm{ZnO}$ increased the light absorption and the adsorption of MO on the surface of the catalyst; hence increasing the photocatalytic activity of the photocatalysts. However, a high content of $\mathrm{GO}(\mathrm{ZnO} / \mathrm{rGO} 20)$ led to a decrement in the photocatalytic activity. Gayathri and co-workers [43] have reported that, at a higher graphene content, the graphene sheets tended to clasp together and appeared like multi-layer graphene after heat treatment. Excess GO also caused a shielding of the active sites on the catalyst surface, and led to the scattering of photons [31, 44, 45]. Since the light absorption of the photocatalyst was reduced, the excitation efficiency of $\mathrm{ZnO}$ was also lowered, consequently reducing the photocatalytic activity of the photocatalysts.

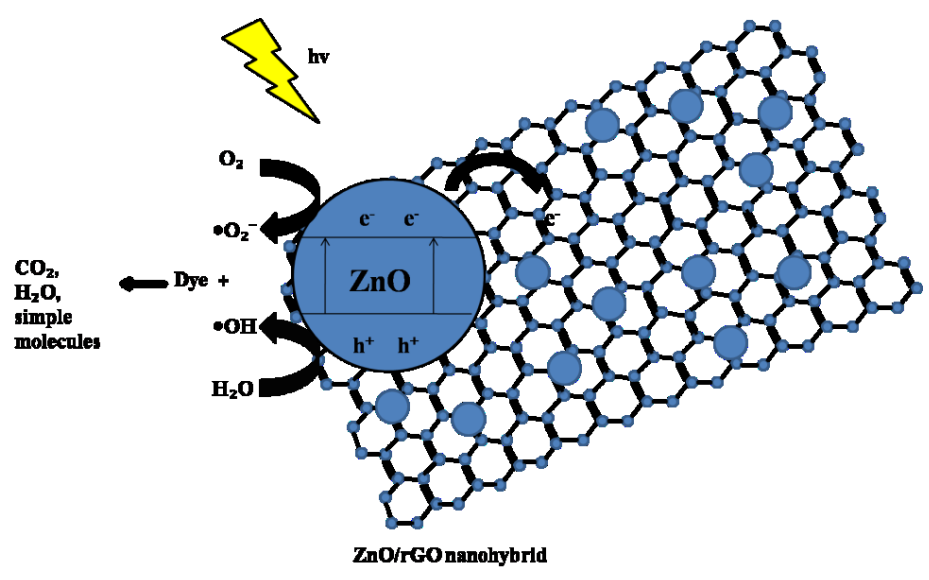

Figure 9. Mechanism of photodegradation

\section{Conclusion}

A series of $\mathrm{ZnO} / \mathrm{rGO}$ nanohybrids with different $\mathrm{GO}$ content was successfully synthesized via a simple and inexpensive precipitation method. The $\mathrm{ZnO}$ particles were formed on the surface of the graphene sheet. The presence of GO during the synthesis inhibited the crystal growth of $\mathrm{ZnO}$ that led to the formation of smaller-sized $\mathrm{ZnO}$ particles. $\mathrm{ZnO} / \mathrm{rGO}$ nanohybrids showed better photodegradation activity compared to $\mathrm{ZnO}$ in degrading methyl orange due to their smaller particle sizes and lower band gap energy. $\mathrm{ZnO} / \mathrm{rGO} 10$ exhibited the highest photocatalytic activity with a kinetic rate constant that was four times higher than pure $\mathrm{ZnO}$. The enhanced photocatalytic activity of the nanohybrids could be attributed to the presence of $\mathrm{rGO}$, an excellent electron acceptor 
which enhanced the active transfer of photogenerated electrons of $\mathrm{ZnO}$ to the rGO sheet, thereby retarding the charge carrier recombination, thus enhancing the charge separation.

\section{Acknowledgements}

The authors would like to thank Universiti Putra Malaysia (UPM) and the Malaysian Government under the Malaysian Exploratory Research Grant Scheme (ERGS-5527187) and UPM-Graduate Research Fellowship award for the financial support for this work.

\section{References}

1. Zainal, Z., Hui, L. K., Hussein, M. Z., Taufiq-Yap, Y. H., Abdullah, A. H. and Ramli, I. (2005). Removal of dyes using immobilized titanium dioxide illuminated by fluorescent lamps. Journal of Hazardous Materials, 125(1): $113-120$.

2. Lin, W.-C., Yang, W.-D. and Jheng, S.-Y. (2012). Photocatalytic degradation of dyes in water using porous nanocrystalline titanium dioxide. Journal of the Taiwan Institute of Chemical Engineers, 43(2): 269 - 274.

3. Chowdhury, S. and Balasubramanian, R. (2014). Graphene/semiconductor nanocomposites (GSNs) for heterogeneous photocatalytic decolorization of wastewaters contaminated with synthetic dyes: A review. Applied Catalysis B: Environmental, 160: 307 - 324.

4. Palanisamy, B., Babu, C., Sundaravel, B., Anandan, S. and Murugesan, V. (2013). Sol-gel synthesis of mesoporous mixed $\mathrm{Fe}_{2} \mathrm{O}_{3} / \mathrm{TiO}_{2}$ photocatalyst: Application for degradation of 4-chlorophenol. Journal of Hazardous Materials, 252: 233 - 242.

5. Ahmad, M., Ahmed, E., Hong, Z., Xu, J., Khalid, N., Elhissi, A. and Ahmed, W. (2013). A facile one-step approach to synthesizing $\mathrm{ZnO} /$ graphene composites for enhanced degradation of methylene blue under visible light. Applied Surface Science, 274: 273 - 281.

6. Shaari, N., Tan, S. and Mohamed, A. (2012). Synthesis and characterization of $\mathrm{CNT} / \mathrm{Ce}-\mathrm{TiO}_{2}$ nanocomposite for phenol degradation. Journal of Rare Earths, 30(7): 651 - 658.

7. Zhu, L.-P., Liao, G.-H., Huang, W.-Y., Ma, L.-L., Yang, Y., Yu, Y. and Fu, S.-Y. (2009). Preparation, characterization and photocatalytic properties of $\mathrm{ZnO}$-coated multi-walled carbon nanotubes. Materials Science and Engineering: B, 163(3): 194 - 198.

8. Klanwan, J., Akrapattangkul, N., Pavarajarn, V., Seto, T., Otani, Y. and Charinpanitkul, T. (2010). Single-step synthesis of MWCNT/ZnO nanocomposite using co-chemical vapor deposition method. Materials Letters, 64(1): 80 - 82.

9. Saleh, T. A., Gondal, M., Drmosh, Q., Yamani, Z. and Al-Yamani, A. (2011). Enhancement in photocatalytic activity for acetaldehyde removal by embedding $\mathrm{ZnO}$ nano particles on multiwall carbon nanotubes. Chemical Engineering Journal, 166(1): 407 - 412.

10. Sakthivel, S., Geissen, S.-U., Bahnemann, D., Murugesan, V. and Vogelpohl, A. (2002). Enhancement of photocatalytic activity by semiconductor heterojunctions: $\alpha-\mathrm{Fe}_{2} \mathrm{O}_{3}, \mathrm{WO}_{3}$ and $\mathrm{CdS}$ deposited on $\mathrm{ZnO}$. Journal of Photochemistry and Photobiology A: Chemistry, 148(1): 283 - 293.

11. Li, B., Liu, T., Wang, Y. and Wang, Z. (2012). ZnO/graphene-oxide nanocomposite with remarkably enhanced visible-light-driven photocatalytic performance. Journal of Colloid and Interface Science, 377(1): 114 - 121.

12. Wang, Z.-I., Xu, D., Huang, Y., Wu, Z., Wang, L.-M. and Zhang, X.-B. (2012). Facile, mild and fast thermaldecomposition reduction of graphene oxide in air and its application in high-performance lithium batteries. Chemical Communications, 48(7): 976 - 978.

13. Liu, Y., Han, G., Li, Y. and Jin, M. (2011). Flower-like zinc oxide deposited on the film of graphene oxide and its photoluminescence. Materials Letters, 65(12): 1885 - 1888.

14. Ameen, S., Akhtar, M. S., Seo, H.-K. and Shin, H. S. (2013). Advanced ZnO-graphene oxide nanohybrid and its photocatalytic applications. Materials Letters, 100: $261-265$.

15. Zhou, X., Shi, T. and Zhou, H. (2012). Hydrothermal preparation of ZnO-reduced graphene oxide hybrid with high performance in photocatalytic degradation. Applied Surface Science, 258(17): 6204 -6211.

16. Leng, Y., Wang, W., Zhang, L., Zabihi, F. and Zhao, Y. (2014). Fabrication and photocatalytical enhancement of $\mathrm{ZnO}$-graphene hybrid using a continuous solvothermal technique. The Journal of Supercritical Fluids, 91: 61 $-67$. 
17. Xu, S., Fu, L., Pham, T. S. H., Yu, A., Han, F. and Chen, L. (2015). Preparation of ZnO flower/reduced graphene oxide composite with enhanced photocatalytic performance under sunlight. Ceramics International, 41(3): 4007 - 4013.

18. Marlinda, A., Huang, N. M., Muhamad, M. R., An'amt, M., Chang, B. Y. S., Yusoff, N., Harrison, I., Lim, H. N., Chia, C. and Kumar, S.V. (2012). Highly efficient preparation of $\mathrm{ZnO}$ nanorods decorated reduced graphene oxide nanocomposites. Materials Letters, 80: 9 - 12.

19. Fu, D., Han, G., Chang, Y. and Dong, J. (2012). The synthesis and properties of ZnO-graphene nano hybrid for photodegradation of organic pollutant in water. Materials Chemistry and Physics, 132(2): 673 - 681.

20. Ming, H. N. (2010). Simple room-temperature preparation of high-yield large-area graphene oxide. International Journal of Nanomedicine, 6: 3443 - 3448.

21. Zhang, Y., Chen, Z., Liu, S. and Xu, Y.-J. (2013). Size effect induced activity enhancement and antiphotocorrosion of reduced graphene oxide/ZnO composites for degradation of organic dyes and reduction of $\mathrm{Cr}(\mathrm{VI})$ in water. Applied Catalysis B: Environmental, 140: 598 - 607.

22. Chen, Y.-L., Hu, Z.-A., Chang, Y.-Q., Wang, H.-W., Zhang, Z.-Y., Yang, Y.-Y. and Wu, H.-Y. (2011). Zinc oxide/reduced graphene oxide composites and electrochemical capacitance enhanced by homogeneous incorporation of reduced graphene oxide sheets in zinc oxide matrix. The Journal of Physical Chemistry C, 115(5): 2563 - 2571.

23. Moussa, H., Girot, E., Mozet, K., Alem, H., Medjahdi, G. and Schneider, R. (2016). ZnO rods/reduced graphene oxide composites prepared via a solvothermal reaction for efficient sunlight-driven photocatalysis. Applied Catalysis B: Environmental, 185: 11 - 21.

24. Samadi, M., Shivaee, H. A., Zanetti, M., Pourjavadi, A. and Moshfegh, A. (2012). Visible light photocatalytic activity of novel MWCNT-doped ZnO electrospun nanofibers. Journal of Molecular Catalysis A: Chemical, 359: $42-48$.

25. Kuo, S.-Y., Chen, W.-C., Lai, F.-I., Cheng, C.-P., Kuo, H.-C., Wang, S.-C. and Hsieh, W.-F. (2006). Effects of doping concentration and annealing temperature on properties of highly-oriented Al-doped $\mathrm{ZnO}$ films. Journal of Crystal Growth, 287(1): 78 - 84.

26. Selvam, N. C. S., Narayanan, S., Kennedy, L. J. and Vijaya, J. J. (2013). Pure and Mg-doped self-assembled $\mathrm{ZnO}$ nano-particles for the enhanced photocatalytic degradation of 4-chlorophenol. Journal of Environmental Sciences, 25(10): 2157 - 2167.

27. Thommes, M., Kaneko, K., Neimark, A. V., Olivier, J. P., Rodriguez-Reinoso, F., Rouquerol, J. and Sing, K. S. (2015). Physisorption of gases, with special reference to the evaluation of surface area and pore size distribution (IUPAC Technical Report). Pure and Applied Chemistry, 87 (9-10): 1051 - 1069.

28. Kavitha, M., Pillai, S. C., Gopinath, P. and John, H. (2015). Hydrothermal synthesis of ZnO decorated reduced graphene oxide: Understanding the mechanism of photocatalysis. Journal of Environmental Chemical Engineering, 3:1194 - 1199.

29. Omar, F. S., Nay Ming, H., Hafiz, S. M. and Ngee, L. H. (2014). Microwave synthesis of zinc oxide/reduced graphene oxide hybrid for adsorption-photocatalysis application. International Journal of Photoenergy, 2014: 1 -8 .

30. Huang, K., Li, Y., Lin, S., Liang, C., Wang, H., Ye, C., Wang, Y., Zhang, R., Fan, D. and Yang, H. (2014). A facile route to reduced graphene oxide-zinc oxide nanorod composites with enhanced photocatalytic activity. Powder Technology, 257: 113 - 119.

31. Peng, Y., Ji, J. and Chen, D. (2015). Ultrasound assisted synthesis of $\mathrm{ZnO} /$ reduced graphene oxide composites with enhanced photocatalytic activity and anti-photocorrosion. Applied Surface Science, 356: 762 - 768.

32. Song, Y., Shao, P., Tian, J., Shi, W., Gao, S., Qi, J., Yan, X. and Cui, F. (2016). One-step hydrothermal synthesis of $\mathrm{ZnO}$ hollow nanospheres uniformly grown on graphene for enhanced photocatalytic performance. Ceramics International, 42(1): 2074 - 2078.

33. Lv, T., Pan, L., Liu, X., Lu, T., Zhu, G. and Sun, Z. (2011). Enhanced photocatalytic degradation of methylene blue by $\mathrm{ZnO}$-reduced graphene oxide composite synthesized via microwave-assisted reaction. Journal of Alloys and Compounds, 509(41): 10086 - 10091.

34. Nipane, S., Korake, P. and Gokavi, G. (2015). Graphene-zinc oxide nanorod nanocomposite as photocatalyst for enhanced degradation of dyes under UV light irradiation. Ceramics International, 41 (3): 4549 - 4557.

35. Yakuphanoglu, F. (2010). Electrical characterization and device characterization of $\mathrm{ZnO}$ microring shaped films by sol-gel method. Journal of Alloys and Compounds, 507(1): 184 - 189. 
36. Tien, H. N., Khoa, N. T., Hahn, S. H., Chung, J. S., Shin, E. W. and Hur, S. H. (2013). One-pot synthesis of a reduced graphene oxide-zinc oxide sphere composite and its use as a visible light photocatalyst. Chemical Engineering Journal, 229: 126 - 133.

37. Morales-Torres, S., Pastrana-Martínez, L. M., Figueiredo, J. L., Faria, J. L. and Silva, A. M. (2013). Graphene oxide-P25 photocatalysts for degradation of diphenhydramine pharmaceutical and methyl orange dye. Applied Surface Science, 275: 361 - 368.

38. Khezrianjoo, S. and Revanasiddappa, H. (2012). Langmuir-Hinshelwood kinetic expression for the photocatalytic degradation of Metanil Yellow aqueous solutions by $\mathrm{ZnO}$ catalyst. Chemical Sciences Journal, 3: 1 - 7 .

39. Liu, Q., Liu, Z., Zhang, X., Yang, L., Zhang, N., Pan, G., Yin, S., Chen, Y. and Wei, J. (2009). Polymer photovoltaic cells based on solution-processable graphene and P3HT. Advanced Functional Materials, 19(6): 894 - 904.

40. Yang, Y. and Liu, T. (2011). Fabrication and characterization of graphene oxide/zinc oxide nanorods hybrid. Applied Surface Science, 257(21): 8950 - 8954.

41. Herring, N. P., Almahoudi, S. H., Olson, C. R. and El-Shall, M. S. (2012). Enhanced photocatalytic activity of ZnO-graphene nanocomposites prepared by microwave synthesis. Journal of Nanoparticle Research, 14(12): 1 $-13$.

42. Wang, X., Zhi, L. and Müllen, K. (2008). Transparent, conductive graphene electrodes for dye-sensitized solar cells. Nano Letters, 8(1): 323 - 327.

43. Gayathri, S., Jayabal, P., Kottaisamy, M. and Ramakrishnan, V. (2014). Synthesis of ZnO decorated graphene nanocomposite for enhanced photocatalytic properties. Journal of Applied Physics, 115(17): 173504.

44. Chen, Z., Zhang, N., and Xu, Y.-J. (2013). Synthesis of graphene-ZnO nanorod nanocomposites with improved photoactivity and anti-photocorrosion. CrystEngComm, 15(15): 3022 - 3030.

45. Sarkar, S. and Basak, D. (2013). The reduction of graphene oxide by zinc powder to produce a zinc oxidereduced graphene oxide hybrid and its superior photocatalytic activity. Chemical Physics Letters, 561: 125 130. 